\title{
Evaluation Potential Antidiabetic Effects of Ferula latisecta in Streptozotocin-Induced Diabetic Rats
}

\author{
Sajad Javanshir ${ }^{2}$, Mohammad Soukhtanloo ${ }^{3}$, Mohammad Jalili-Nik ${ }^{3}$, Amirali Jahani Yazdi ${ }^{4}$, \\ Mohammad Sadegh Amiri ${ }^{5}$, Ahmad Ghorbani ${ }^{1}$ * \\ ${ }^{1}$ Pharmacological Research Center of Medicinal Plants, Mashhad University of Medical Sciences, Mashhad, Iran \\ ${ }^{2}$ Student Research Committee, School of Dentistry, Mashhad University of Medical Sciences, Mashhad, Iran \\ ${ }^{3}$ Department of Clinical Biochemistry, Faculty of Medicine, Mashhad University of Medical Sciences, Mashhad, Iran \\ ${ }^{4}$ Department of Laboratory Sciences, School of Paramedical Sciences, Mashhad University of Medical Sciences, Mashhad, Iran \\ ${ }^{5}$ Department of Biology, Payame Noor University, Tehran, Iran
}

Received April 4, 2018

Reviewed August 14, 2018

Accepted June 15, 2020

\section{*Correspondence}

Ahmad Ghorbani

Research Associate Professor,

Pharmacological Research Center of

Medicinal Plants, Faculty of Medicine,

Pardis campus, Azadi Square, Mashhad, Iran

Tel: +98-513-800-2256

E-mail: ghorbania@mums.ac.ir
Objectives: The aim of the present work was to evaluate the possible beneficial effects of $F$. latisecta on blood glucose, lipids, and diabetes-related changes in the liver and kidney of streptozotocin-induced diabetic rats.

Methods: Male Wistar rats were randomly allocated into four groups $(n=6)$ : normal control rats, diabetic control rats, diabetic rats treated for 4 weeks with $F$. latisecta root (400 $\mathrm{mg} / \mathrm{kg} /$ day), and diabetic rats treated with $F$. latisecta aerial parts $(400 \mathrm{mg} / \mathrm{kg} /$ day).

Results: Induction of diabetes significantly $(p<0.05)$ increased the levels of fasting blood glucose (FBG), triglyceride, total cholesterol, low-density lipoprotein (LDL), blood urea nitrogen (BUN), aspartate aminotransferase (AST), and alanine aminotransferase (ALT). Diabetes also increased $(p<0.05)$ oxidative stress in the kidney and liver (decrease of thiol and increase of superoxide dismutase). The root and aerial parts of $F$. latisecta significantly reduced the level of LDL $(p<0.05)$ and restored the content of thiol $(p<0.05)$ and superoxide dismutase $(p<0.01)$ in the kidney and liver. $F$. latisecta had no significant effect on the levels of FBG, BUN, AST, and ALT. The root of $F$. latisecta also reduced the serum level of total cholesterol $(p<0.05)$ and prevented the progression of hyperglycemia.

Conclusion: These findings suggest that $F$. latisecta may improve diabetic dyslipidemia by reducing serum LDL. Further studies are needed to confirm our findings.

Keywords: diabetes, Ferula, glucose, lipids, oxidative stress

\section{INTRODUCTION}

An increasing number of diabetic patients use medicinal plants to control their blood glucose [1]. It is estimated that 60$70 \%$ of Korean diabetic patients experience complementary and alternative medicine, of which approximately $60 \%$ use various types of plants $[2,3]$. In recent decades, academic studies have confirmed the beneficial effects of medicinal plants in the management of diabetes $[4,5]$. These beneficial effects include improving glycemic control, reducing serum lipids, inhibiting oxidative stress, and ameliorating inflammatory responses $[6,7]$.

In traditional medicine of Middle East, a number of plants in the genus of Ferula (family: Apiaceae) such as F. hermonis, $F$. assa-foetida, and $F$. narthex are used for controlling diabetes [8-10]. Results of experimental and clinical investigations are in agreement with the traditional uses of these plants for reducing blood glucose and lipids and for improving diabetic complications [11-15]. For example, it has been shown that $F$. assafoetida reduced blood glucose and increased serum insulin in alloxan-induced diabetic rats [12]. This plant showed fat lowering, anti-obesity, and liver steatosis protective effects in type 2 diabetic rats [11]. Also, F. hermonis was shown to reduce serum lipids and improve erectile dysfunction in the diabetic patient [13]. 
Ferula latisecta Rech.f. \& Aellen is one of the plants of genus Ferula which was commonly known as "Koma Hezar-Masjed" and "Sasekoma" in Iran [16-18]. In the folk medicine of northeast Iran, F. latisecta is used for treating parasitic diseases, relieve infant stomach ache, and controlling diabetes. In previous studies, it has been shown that the essential oil from the aerial parts of $F$. latisecta has an antimicrobial effect $[19,20]$. However, so far no academic study has tested the anti-diabetic activity of this plant. The aim of the present work was to evaluate the possible beneficial effects of $F$. latisecta on blood glucose, lipids, and diabetes-related changes in the liver and kidney of streptozotocin-induced hyperglycemic rats.

\section{MATERIALS AND METHODS}

\section{Materials}

The whole parts of $F$. latisecta (root, stem, leaves, and fruits) were freshly collected from Zarrin-Kuh Mountains, Northeast Iran (Fig. 1). The plant was identified at the herbarium of Dargaz Payame Noor University, where a voucher specimen was deposited (No. 477). The roots and aerial parts were separately washed, dried in shadow, and ground into powder using a grinder. Trichloroacetic acid (TCA), streptozotocin, 2,20-dinitro-5,50dithiodibenzoic acid (DTNB), thiobarbituric acid (TBA), and

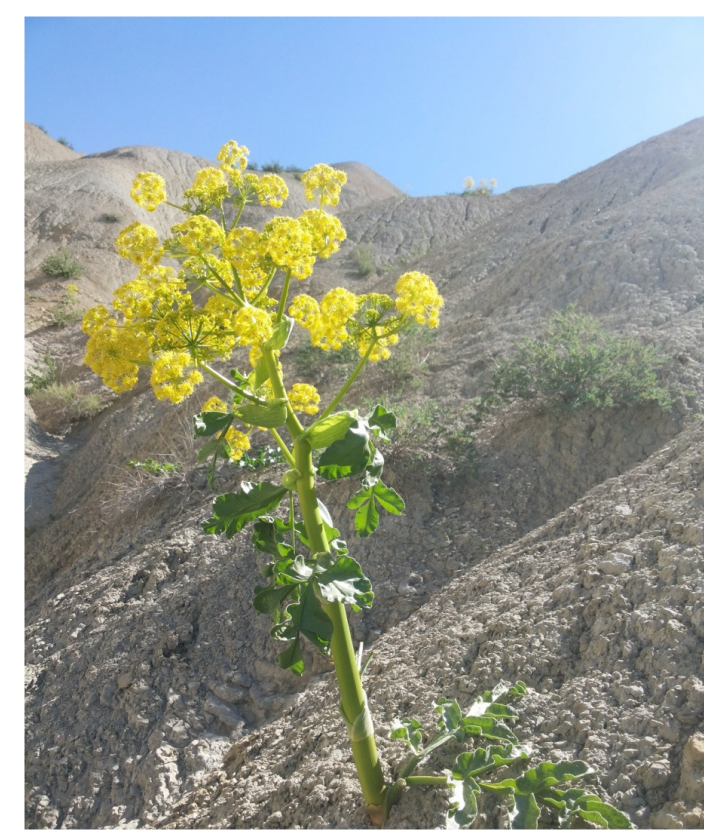

Figure 1. Aerial parts of Ferula latisecta. 3-(4,5-dimethylthiazol-2-yl)-2,5-diphenyl tetrazolium (MTT) were purchased from Sigma (St. Louis, USA).

\section{Animals}

Adult male Wistar rats (220-270 g) were obtained from the Laboratory Animals Research Center at Mashhad University of Medical Sciences. The animals were housed in polypropylene cages under light and temperature-controlled conditions (12 h dark/light cycle; $22 \pm 4^{\circ} \mathrm{C}$ ). They had free access to water and rat pellets ad libitum. The research was performed in accordance with the internationally accepted principles for laboratory animal use and approved by the animal ethical committee of Mashhad University of Medical Sciences (ethical code: IR.MUMS.fm.REC.1396.623).

\section{Experimental design}

A total of 24 rats were randomly allocated into four groups $(n=6)$ : normal control rats; diabetic control rats; diabetic rats treated with F. latisecta root at dose of $400 \mathrm{mg} / \mathrm{kg} /$ day; and diabetic rats treated with $400 \mathrm{mg} / \mathrm{kg} /$ day of $F$. latisecta aerial parts (stem, leaves, and fruits). The powder of the root and aerial parts were added to food pellets and the dose of the plant materials was adjusted weekly based on the amount of food intake and body weight. Considering the body surface area for dose translation from animals to humans, a dose of $400 \mathrm{mg} / \mathrm{kg}$ in the rat is approximately equal to $64 \mathrm{mg} / \mathrm{kg}$ in human (i.e., $4.5 \mathrm{~g}$ per day for people weighing $70 \mathrm{~kg}$ ) [21]. In traditional medicine, the whole parts of $F$. latisecta are added to foods (i.e., soup) or approximately 3-5 $\mathrm{g}$ of the leaves is consumed in the form of decoction.

For the induction of diabetes, streptozotocin was injected intraperitoneally at a dose of $65 \mathrm{mg} / \mathrm{kg}$. After $72 \mathrm{~h}$, fasting blood glucose (FBG) was measured by a glucometer (Accu-Check Active, Roche, Mannheim, Germany) and the animals with FBG of $200 \mathrm{mg} / \mathrm{dL}$ or higher were considered diabetic [22, 23]. Administration of $F$. latisecta was started $72 \mathrm{~h}$ after streptozotocin injection and continued for 4 weeks.

\section{Serum biochemical analysis}

At the end of the study, blood samples were collected by cardiac puncture after $12 \mathrm{~h}$ fasting. The samples were centrifuged for $10 \mathrm{~min}$ at $3000 \mathrm{rpm}$ and the obtained serums were analyzed 
using an automated biochemistry analyzer (BT 3000 plus, Biotecnica Instruments, Italy). The measured parameters included glucose, triglyceride, cholesterol, low-density lipoprotein (LDL), high-density lipoprotein (HDL), blood urea nitrogen (BUN), creatinine, aspartate aminotransferase (AST), and alanine aminotransferase (ALT).

\section{Evaluation of lipid peroxidation}

The level of lipid peroxidation in the liver and kidney was estimated by measuring malondialdehyde level as the product of lipid peroxidation. A sample of $0.5 \mathrm{~mL}$ of the tissue homogenates was mixed with $0.5 \mathrm{~mL}$ of deionized water and $0.5 \mathrm{~mL}$ of TBA reagent (TCA $15 \%$ and TBA $0.37 \%, \mathrm{HCl} 0.25 \mathrm{~N}$ ). Then, the mixture was incubated at $95^{\circ} \mathrm{C}$ for $60 \mathrm{~min}$. After cooling to room temperature, $25 \mu \mathrm{L}$ of $\mathrm{HCl}$ and $1.5 \mathrm{~mL}$ of n-butanol were added to the mixture and centrifuged for $10 \mathrm{~min}$ at $1000 \mathrm{rpm}$. The fluorescence intensity of the supernatant was measured at $485 \mathrm{~nm}$ excitation and $535 \mathrm{~nm}$ emission using a fluorescent plate reader (PerkinElmer VICTOR X5 USA). Tetraethoxypropane was used to prepare a standard curve at concentration ranges between 10-200 $\mu \mathrm{mol} / \mathrm{L}$.

\section{Measurement of total thiol groups}

The content of thiol groups in the liver and kidney was measured using the DTNB reagent. A sample of $50 \mu \mathrm{L}$ of the tissue homogenate was added to $1 \mathrm{~mL}$ of Tris-EDTA buffer ( $\mathrm{pH}$ 8.6). The absorbance was measured at $412 \mathrm{~nm}$ against TrisEDTA buffer alone (A1). Then, $20 \mu \mathrm{L}$ of DTNB $(10 \mathrm{mmol} / \mathrm{L}$ in methanol) was added to this mixture and the absorbance was measured again (A2). The optical density of DTNB reagent (B) was also determined. The level of total thiol in the tissues was calculated from the following equation:

Thiol concentration $(\mathrm{mmol} / \mathrm{L})=[(\mathrm{A} 2-\mathrm{A} 1-\mathrm{B}) \times 1.07 /$

$$
(0.05 \times 13.6)] \text {. }
$$

\section{Superoxide dismutase (SOD) activity assay}

The SOD activity in the liver and kidney was assessed by a calorimetric technique as reported previously [24]. The basis of this assay is the inhibition of the formation of superoxide anion as a result of the auto-oxidation of pyrogallol and MTT. The activity of SOD was expressed as unit per mg tissue protein.

\section{Statistical analysis}

Statistical differences between the study groups were assessed using one-way analysis of variance followed by LSD post hoc test for multiple comparisons. Paired-sample $t$-test was used to compare data obtained before and after treatment. Data are presented as mean \pm SEM and a p-value less than 0.05 was statistically significant.

\section{RESULTS}

\section{The body weight, food consumption, and water intake}

The effects of $F$. latisecta intervention on diabetes-induced weight loss, polyphagia, and polydipsia are shown in Table 1.

Table 1. Effects of $F$. latisecta on the body weight, water intake, and food intake

\begin{tabular}{|c|c|c|c|c|}
\hline Parameters & Normal control & Diabetic control & $\begin{array}{c}\text { Diabetic } \\
\text { F. latisecta (Root) }\end{array}$ & $\begin{array}{c}\text { Diabetic } \\
\text { F. latisecta (Aerial parts) }\end{array}$ \\
\hline \multicolumn{5}{|l|}{ Body weight (g) } \\
\hline Week 4 & $300 \pm 7^{\# \#}$ & $200 \pm 11 * * * \#$ & $195 \pm 12 * * * \#$ & $206 \pm 5 * * * \# \#$ \\
\hline \multicolumn{5}{|c|}{ Water intake (mL/24 h) } \\
\hline Week 4 & $52 \pm 4$ & $117 \pm 8 * * *$ & $119 \pm 6 * * *$ & $120 \pm 8 * * *$ \\
\hline \multicolumn{5}{|l|}{ Food intake (g/24 h) } \\
\hline Week 1 & $24 \pm 1$ & $36 \pm 4 * * *$ & $30 \pm 2 *$ & $32 \pm 2 *$ \\
\hline Week 4 & $22 \pm 1$ & $32 \pm 4 * *$ & $27 \pm 2^{*}$ & $27 \pm 3^{*}$ \\
\hline
\end{tabular}

Data are expressed as mean \pm SEM $(n=6) .{ }^{*} p<0.05, * * p<0.01, * * * p<0.001$ versus normal control; ${ }^{\# \#} p<0.01$ versus day 1 in the corresponding group. 
At the start of treatment, there was a homogeneity between the animal groups in terms of body weight. At the end of the study, the normal control group showed an increased body weight compared to day $1(\mathrm{p}<0.01)$. However, a significant decrease in the body weight was observed in the diabetic control group $(\mathrm{p}$ $<0.01$ ) in spite of a significant increase in consumption of food and water $(\mathrm{p}<0.05-\mathrm{p}<0.001)$. Treatment with the roots or aerial parts of $F$. latisecta had no significant effect on the body weight, water intake, and food consumption.

\section{Blood glucose and lipids}

Injection of streptozotocin significantly increased ( $\mathrm{p}<0.001)$ the level of FBG as compared to normal control rats (Table 2). After 4 weeks, the diabetic control group showed further increase in FBG level (10\%). Administration of F. latisecta root prevented the progression of hyperglycemia. Treatment with the aerial parts of $F$. latisecta had no significant effect on FBG.

The levels of triglycerides, total cholesterol, and LDL in the serum of diabetic control rats were higher than those in normal control rats $(p<0.05)$. A significant decrease in the levels of total cholesterol $(\mathrm{p}<0.05)$ and LDL $(\mathrm{p}<0.05)$ was observed in the group treated with $F$. latisecta root when compared to the untreated group. The LDL level was also lower in the group received aerial parts of $F$. latisecta than the group of untreated diabetic rats $(\mathrm{p}<0.05)$.

\section{Effects of $F$. latisecta on the kidney and liver}

The non-treated diabetic rats showed a significant increase in BUN level when compared to the normal control rats $(\mathrm{p}<$ 0.001 , Table 3). Treatment with the roots or aerial parts of $F$. latisecta had no significant effect on the BUN level with respect to the diabetic control group. Induction of diabetes also increased the levels of serum liver enzymes ALT and ALP ( $p<$ 0.01 ). Again, the roots and aerial parts of $F$. latisecta had no significant effect on the level of ALT and AST.

\section{Effects of $F$. latisecta on tissue oxidative stress}

The content of thiol groups in the kidney and liver of diabetic control rats was significantly lower than those in normal control rats $(\mathrm{p}<0.05)$ (Table 4$)$. Administration of both the root and aerial parts of $F$. latisecta to diabetic animals significantly increased the thiol content in these tissues $(\mathrm{p}<0.05)$. A significant increase in the activity of SOD was observed in the renal

Table 2. Effects of $F$. latisecta on the levels of blood glucose and lipids

\begin{tabular}{|c|c|c|c|c|}
\hline Parameters & Normal control & Diabetic control & $\begin{array}{c}\text { Diabetic } \\
\text { F. latisecta (Root) }\end{array}$ & $\begin{array}{c}\text { Diabetic } \\
\text { F. latisecta (Aerial parts) }\end{array}$ \\
\hline FBG Day 1 (mg/dL) & $98 \pm 5$ & $335 \pm 45 * * *$ & $352 \pm 14$ & $326 \pm 23$ \\
\hline Triglyceride Week 4 (mg/dL) & $55 \pm 10$ & $64 \pm 13^{*}$ & $65 \pm 12$ & $63 \pm 11$ \\
\hline TC Week 4 (mg/dL) & $66 \pm 4$ & $95 \pm 8 * *$ & $78 \pm 7^{\#}$ & $83 \pm 5$ \\
\hline HDL Week 4 (mg/dL) & $40 \pm 2$ & $38 \pm 2$ & $42 \pm 3$ & $46 \pm 2$ \\
\hline
\end{tabular}

Data are expressed as mean \pm SEM $(n=6)$. FBG, fasting blood glucose; HDL, high-density lipoprotein; LDL, low-density lipoprotein; TC, total cholesterol. ${ }^{*} p<0.05, * * p<0.01, * * * p<0.001$ versus normal control; ${ }^{*} p<0.05$ versus diabetic control.

Table 3. Effects of $F$. latisecta on the serum parameters of the kidney and liver functions

\begin{tabular}{lcccc}
\hline \multicolumn{1}{c}{ Parameters } & Normal control & Diabetic control & Diabetic & Diabetic \\
F. latisecta (Root) & F. latisecta (Aerial parts) \\
\hline Creatinine (mg/dL) & $0.67 \pm 0.02$ & $0.65 \pm 0.02$ & $0.68 \pm 0.05$ & $0.64 \pm 0.05$ \\
BUN (mg/dL) & $52 \pm 5$ & $130 \pm 7 * * *$ & $146 \pm 10$ & $138 \pm 8$ \\
AST (U/L) & $132 \pm 8$ & $760 \pm 196 * *$ & $760 \pm 187$ & $526 \pm 139$ \\
ALT (U/L) & $57 \pm 3$ & $513 \pm 159 * *$ & $530 \pm 177$ & $302 \pm 91$ \\
\hline
\end{tabular}

Fasting blood samples were obtained at the end of study (week 4). Data are expressed as mean \pm SEM $(n=6) . * * p<0.01, * * * p<0.001$ versus normal control. 
Sajad Javanshir, et al.

Table 4. Effects of F. latisecta on the levels of thiol groups, malondialdehyde (MDA), and superoxide dismutase (SOD) in the kidney and liver

\begin{tabular}{|c|c|c|c|c|}
\hline Parameters & Normal control & Diabetic control & $\begin{array}{c}\text { Diabetic } \\
\text { F. latisecta (Root) }\end{array}$ & $\begin{array}{c}\text { Diabetic } \\
\text { F. latisecta (Aerial parts) }\end{array}$ \\
\hline \multicolumn{5}{|c|}{ Thiol ( $\mu \mathrm{mol} / \mathrm{mg}$ protein) } \\
\hline Kidney & $25 \pm 8$ & $5 \pm 1.5^{*}$ & $41 \pm 12^{\# \#}$ & $26 \pm 6^{\#}$ \\
\hline Liver & $26 \pm 6$ & $5 \pm 0.5 *$ & $27 \pm 7^{\# \#}$ & $33 \pm 6^{\# \#}$ \\
\hline \multicolumn{5}{|c|}{ MDA (nmol/mg protein) } \\
\hline Kidney & $350 \pm 40$ & $1,690 \pm 110 * *$ & $1,180 \pm 405$ & $1,770 \pm 327$ \\
\hline Liver & $905 \pm 250$ & $970 \pm 90$ & $641 \pm 142$ & $1,010 \pm 173$ \\
\hline \multicolumn{5}{|c|}{ SOD (Unit/mg protein) } \\
\hline Kidney & $105 \pm 5$ & $225 \pm 30 * * *$ & $119 \pm 12^{\# \# \#}$ & $125 \pm 17^{\# \#}$ \\
\hline Liver & $100 \pm 8$ & $235 \pm 25 * * *$ & $73 \pm 5^{\# \# \#}$ & $147 \pm 24^{\# \#}$ \\
\hline
\end{tabular}

Fasting blood samples were obtained at the end of study (week 4). Data are expressed as mean \pm SEM $(n=6) .{ }^{*} p<0.05, * * p<0.01, * * * p<0.001$ versus normal control; ${ }^{\#} p<0.05,{ }^{\# \#} p<0.01,{ }^{\# \# \#} p<0.001$ versus diabetic control.

and hepatic tissues of rats in the diabetic control group when compared with the normal control group $(\mathrm{p}<0.001)$. Both the root and aerial parts of $F$. latisecta could inhibit the diabetesinduced increase of SOD activity. Measurement of MDA level showed a significant increase of lipid peroxidation in the renal tissue of diabetic rats $(\mathrm{p}<0.01)$, which was not affected by $F$. latisecta.

\section{DISCUSSION}

Some plants of the genus Ferula are used in the traditional medicine of the Middle East for management of diabetes [8-10]. The aim of this study was to examine the beneficial effects of $F$. latisecta on blood glucose, lipids, and diabetes-related changes in the kidney and liver of streptozotocin-induced hyperglycemic rats. Streptozotocin induces diabetes by reducing insulin production and secretion because of the destruction of the pancreatic beta cells [25]. Therefore, the animals show symptoms of type-1 diabetes including hypoinsulinemia, hyperglycemia, polyuria, polydipsia, and weight loss $[26,27]$. In this model of diabetic rats, the root, and aerial parts of $F$. latisecta could not improve symptoms of diabetes (polydipsia, polyuria, and weight loss).

Regarding blood glucose, the untreated diabetic group displayed a further increase in FBG level at week 4 compared to day 1. Although the level of FBG in F. latisecta root group was not statistically different from the diabetic control group, the root could inhibit the further increase in FBG level. Although this is the first study to evaluate the effect of F. latisecta on blood glucose, one previous study reported that $F$. assa-foetida, one other plant in the genus of Ferula, reduces blood glucose and increases serum insulin in diabetic rats [12]. One of the limitations of the present work is that we did not perform a glucose tolerance test after $F$. latisecta administration. It is possible that this plant can reduce postprandial hyperglycemia, which should be examined in future studies.

Dyslipidemia is one of the main risk factors for developing diabetic complications particularly cardiovascular diseases [25, 28]. Diabetic dyslipidemia is characterized by an increase of serum triglyceride and LDL and a decrease of HDL level [29]. A large number of patients with diabetes do not reach a normal level of serum LDL despite treatment with current hypolipidemic drugs (e.g., statins) [30, 31]. Therefore, studies for finding new hypolipidemic agents are still desirable. In our study, diabetic rats presented dyslipidemia, as judged by increased levels of total cholesterol, triglycerides, and LDL. Treatment with F. latisecta root significantly reduced the elevated levels of LDL and total cholesterol. LDL is the primary goal of lipid-lowering therapy in diabetic patients, however, despite current drug therapy, a large number of these patients do not reach the goal level for LDL (less than $100 \mathrm{mg} / \mathrm{dL}$ ) [30].

The hypolipidemic effect of $F$. latisecta may be helpful in preventing cardiovascular events in diabetic patients.

Streptozotocin-induced diabetes is associated with an increase in the activity of serum ALT and AST [23, 32, 33]. Elevation of the activity of these enzymes is an indicator of liver disorders (e.g., fatty liver disease and decreased hepatic insulin sensitivity) and is observed more frequently among diabetic 
individuals than healthy subjects [34-37]. Although F. latisecta could reduce streptozotocin-induced oxidative stress (restoring the levels of SOD and thiol) in the liver and kidney, it was not able to decrease serum level of liver enzymes. This may be due to the inability of $F$. latisecta to improve FBG and metabolic symptoms of diabetes (i.e., weight loss, polyphagia, and polydipsia).

\section{CONCLUSION}

The findings of the present study suggest that $F$ latisecta may improve diabetic dyslipidemia by reducing serum LDL. Also, although this plant has no hypoglycemic effect, its root can prevent the progression of hyperglycemia in the streptozotocin model of type-1 diabetes. Further studies are needed to confirm our findings.

\section{ACKNOWLEDGMENT}

The present work was supported by Vice-Chancellor for Research and Technology, Mashhad University of Medical Sciences (grant number: 960305).

\section{CONFLICT OF INTEREST}

The authors report no declarations of interest.

\section{FINANCIAL SUPPORT}

No financial support was provided for this work.

\section{ORCID}

Sajad Javanshir, https://orcid.org/0000-0003-2728-4181

Mohammad Soukhtanloo, https://orcid.org/0000-0003-2145-125X

Mohammad Jalili-Nik, https://orcid.org/0000-0002-1259-4593

Amirali Jahani Yazdi, https://orcid.org/0000-0002-5503-5310

Mohammad Sadegh Amiri, https://orcid.org/0000-0003-2892-4523

Ahmad Ghorbani, https://orcid.org/0000-0002-1603-2619

\section{REFERENCES}

1. Egede LE, Ye X, Zheng D, Silverstein MD. The prevalence and pattern of complementary and alternative medicine use in individuals with diabetes. Diabetes Care. 2002;25(2):324-9.
2. Kim YS, Chun JH, Park JH, Kang CI. Status and associating factors of complementary and altemative medicine among Korean diabetic patients. J Korean Diabetes Assoc. 2000;24(1):78-89.

3. Lee MS, Lee MS, Lim HJ, Moon SR. Survey of the use of complementary and alternative medicine among Korean diabetes mellitus patients. Pharmacoepidemiol Drug Saf. 2004;13(3):16771.

4. Ghorbani A. Best herbs for managing diabetes: a review of clinical studies. Braz J Pharm Sci. 2013;49(3):413-22.

5. Hosseini A, Shafiee-Nick R, Ghorbani A. Pancreatic beta cell protection/regeneration with phytotherapy. Braz J Pharm Sci. 2015;51(1):1-16.

6. Prabhakar PK, Doble M. Mechanism of action of natural products used in the treatment of diabetes mellitus. Chin J Integr Med. 2011;17(8):563-74.

7. Ghorbani A. Mechanisms of antidiabetic effects of flavonoid rutin. Biomed Pharmacother. 2017;96:305-12.

8. Afifi-Yazar FU, Kasabri V, Abu-Dahab R. Medicinal plants from Jordan in the treatment of diabetes: traditional uses vs. in vitro and in vivo evaluations--part 2. Planta Med. 2011;77(11):121020.

9. Otoom SA, Al-Safi SA, Kerem ZK, Alkofahi A. The use of medicinal herbs by diabetic Jordanian patients. J Herb Pharmacother. 2006;6(2):31-41.

10. Yaseen G, Ahmad M, Zafar M, Sultana S, Kayani S, Cetto AA, et al. Traditional management of diabetes in Pakistan: ethnobotanical investigation from Traditional Health Practitioners. J Ethnopharmacol. 2015;174:91-117.

11. Azizian H, Ebrahim Rezvani M, Esmaeilidehaj M, Bagheri SM. Anti-obesity, fat lowering and liver steatosis protective effects of ferula asafoetida gum in type 2 diabetic rats: possible involvement of leptin. Iran J Diabetes Obes. 2012;4(3):120-6.

12. Abu-Zaiton AS. Anti-diabetic activity of Ferula assafoetida extract in normal and alloxan-induced diabetic rats. Pak J Biol Sci. 2010;13(2):97-100.

13. Hedaya MA, Hegazy SK, Salem KA, El-Kawy KSA. Evaluation of the clinical effect of Zallouh extract (Ferula hermonis) on diabetic patients with erectile dysfunction. J Pan Arab Leag Dermatol. 2007;18(1):17-26.

14. Raafat K, El-Lakany A. Acute and subchronic in-vivo effects of Ferula hermonis L. and Sambucus nigra L. and their potential active isolates in a diabetic mouse model of neuropathic pain. BMC Complement Altern Med. 2015;15:257.

15. Naguib YMA, inventor; Herbal compositions and methods for diabetes and weight loss management. United States patent US 6,780,440. 2004 Aug 24.

16. Iranshahi M, Amanolahi F, Schneider B. New sesquiterpene coumarin from the roots of Ferula latisecta. Avicenna J Phytomed. 


\section{2;2(3):133-8}

17. Mozaffarian V. Identification of medicinal and aromatic plants of Iran. Tehran: Farhang Moaser Publishers; 2013. 1350 p.

18. Amiri MS, Joharchi MR. Ethnobotanical knowledge of Apiaceae family in Iran: a review. Avicenna J Phytomed. 2016;6(6):621-35.

19. Habibi Z, Salehi P, Yousefi M, Hejazi Y, Laleh A, Mozaffarian $\mathrm{V}$, et al. Chemical composition and antimicrobial activity of the essential oils of Ferula latisecta and Mozaffariania insignis from Iran. Chem Nat Compd. 2006;42(6):689-92.

20. Iranshahi M, Hassanzadeh-Khayat M, Bazzaz BSF, Sabeti Z, Enayati F. High content of polysulphides in the volatile oil of Ferula latisecta Rech. F. et Aell. fruits and antimicrobial activity of the oil. J Essent Oil Res. 2008;20(2):183-5.

21. Reagan-Shaw S, Nihal M, Ahmad N. Dose translation from animal to human studies revisited. FASEB J. 2008;22(3):659-61.

22. Jalili-Nik M, Soukhtanloo M, Javanshir S, Jahani Yazdi A, Esmaeilizadeh M, Jafarian $\mathrm{AH}$, et al. Effects of ethanolic extract of Ferula gummosa oleo-resin in a rat model of streptozotocininduced diabetes. Res Pharm Sci. 2019;14(2):138-45.

23. Hosseini A, Mollazadeh H, Amiri MS, Sadeghnia HR, Ghorbani A. Effects of a standardized extract of Rheum turkestanicum Janischew root on diabetic changes in the kidney, liver and heart of streptozotocin-induced diabetic rats. Biomed Pharmacother. 2017;86:605-11.

24. Madesh M, Balasubramanian KA. Microtiter plate assay for superoxide dismutase using MTT reduction by superoxide. Indian J Biochem Biophys. 1998;35(3):184-8.

25. Szkudelski T. The mechanism of alloxan and streptozotocin action in B cells of the rat pancreas. Physiol Res. 2001;50(6):53746.

26. Okon UA, Owo DU, Udokang NE, Udobang JA, Ekpenyong CE. Oral administration of aqueous leaf extract of Ocimum gratissimum ameliorates polyphagia, polydipsia andweight loss in streptozotocin-induced diabetic rats. Am J Med Med Sci. 2012; 2(3):45-9.

27. de Moura Barbosa H, Amaral D, do Nascimento JN, Machado DC, de Sousa Araújo TA, de Albuquerque UP, et al. Spondias tuberosa inner bark extract exert antidiabetic effects in streptozotocin-induced diabetic rats. J Ethnopharmacol. 2018;227:24857.
28. Viljoen A, Joshi S, Wierzbicki AS. Diabetic dyslipidemia and risk of cardiovascular disease. In: Holt RIG, Cockram CS, Flyvbjerg A, Goldstein BJ, editors. Textbook of diabetes. 5th ed. Chichester: Wiley Blackwell; 2017. p. 643-52.

29. Dake AW, Sora ND. Diabetic dyslipidemia review: an update on current concepts and management guidelines of diabetic dyslipidemia. Am J Med Sci. 2016;351(4):361-5.

30. Vijayaraghavan K. Treatment of dyslipidemia in patients with type 2 diabetes. Lipids Health Dis. 2010;9(1):144.

31. Karalis DG. The role of lipid-lowering therapy in preventing coronary heart disease in patients with type 2 diabetes. Clin Cardiol. 2008;31(6):241-8.

32. Shafiee-Nick R, Ghorbani A, Vafaee Bagheri F, Rakhshandeh H. Chronic administration of a combination of six herbs inhibits the progression of hyperglycemia and decreases serum lipids and aspartate amino transferase activity in diabetic rats. Adv Pharmacol Sci. 2012;2012:789796.

33. Tashakori-Sabzevar F, Ramezani M, Hosseinzadeh H, Parizadeh SM, Movassaghi AR, Ghorbani A, et al. Protective and hypoglycemic effects of celery seed on streptozotocin-induced diabetic rats: experimental and histopathological evaluation. Acta Diabetol. 2016;53(4):609-19.

34. Forlani G, Di Bonito P, Mannucci E, Capaldo B, Genovese S, Orrasch $\mathrm{M}$, et al. Prevalence of elevated liver enzymes in Type 2 diabetes mellitus and its association with the metabolic syndrome. J Endocrinol Invest. 2008;31(2):146-52.

35. Malenica M, Prnjavorac B, Causevic A, Dujic T, Bego T, Semiz S. Use of databases for early recognition of risk of diabetic complication by analysis of liver enzymes in Type 2 diabetes mellitus. Acta Inform Med. 2016;24(2):90-3.

36. Schindhelm RK, Diamant M, Dekker JM, Tushuizen ME, Teerlink T, Heine RJ. Alanine aminotransferase as a marker of non-alcoholic fatty liver disease in relation to type 2 diabetes mellitus and cardiovascular disease. Diabetes Metab Res Rev. 2006;22(6):437-43.

37. Vozarova B, Stefan N, Lindsay RS, Saremi A, Pratley RE, Bogardus $\mathrm{C}$, et al. High alanine aminotransferase is associated with decreased hepatic insulin sensitivity and predicts the development of type 2 diabetes. Diabetes. 2002;51(6):1889-95. 